\title{
SOME COUNTRIES' EXPERIENCE IN ORGANIZING PROFESSIONAL TRAINING AND ACTIVITY OF PROBATION OFFICERS
}

\begin{abstract}
In the article, some countries' experience in organizing professional training and activities of probation officers has been analyzed. Based on comparative analysis of activities of the Probation Institute abroad, it has been determined that probation service has different functional and organizational features in individual countries. For instance, probation service in different countries is subordinate to different agencies. Thus, probation service in Great Britain, Denmark, Japan, Finland, Norway, Latvia, the Czech Republic and Estonia is under the control of the Ministry of Justice; in the USA, Germany, Hungary, it is subordinate to the judiciary; in the Netherlands - public prosecutor's office; in Sweden - prison authorities; in Singapore, probation service is under the guidance of the Ministry of Community Development and Sports. Another difference consists in the fact that in some countries the law defines probation as punishment (Sweden, Finland, Latvia), whereas in other countries it refers to some criminal measures (Great Britain), exemption from punishment (Estonia) or is not determined at all (the USA). Despite the differences, the goals and means of achieving them in each probation service are similar in the context of criminal law. The approaches to professional training of probation officers have been analyzed and relevant conclusions have been drawn regarding organization of probation officers' professional training in Ukraine. In particular, work with offenders should be performed by highly qualified specialists who have a degree and who have passed specialized training courses in educational institutions subordinate to probation authorities. It is important that the content of probation officers' professional training should be constantly updated, taking into account new approaches and methods of working with convicts, which are recognized as effective.

Keywords: probation, probation service, probation officer, professional training, staff training, resocialization, education, learning.

\section{INTRODUCTION}

In foreign law there are criminal law institutes that allow exempting from punishment foreseen for committing a crime and, under certain conditions, replacing it with alternative criminal and legal measures. Such institutes include the Probation Institute, the Institute of Summary Probation and the Parole (Release) Institute. In Ukraine, the Probation Institute is only being formed, whereas in the leading countries of the world, in particular Great Britain, the United States, France, etc., it has existed for more than 200 years. Therefore, Ukrainian scholars should study, compare, generalize and introduce the best achievements of this experience.
\end{abstract}




\section{THE AIM OF THE STUDY}

The aim of the study is to analyze effective activities of the Probation Institute in some countries, namely, Great Britain, the United States and Canada, and investigate how the system of probation officers' professional training is organized. The leading criterion for choosing countries has become the level of the Probation Institute development.

\section{THEORETICAL FRAMEWORK AND RESEARCH METHODS}

The experience of probation service functioning in some countries has been studied mainly through the prism of functional, communicative and organizational approaches to professional training of probation officers, partly mentioned in European probation (Confederation of European Probation (CEP)), British probation (HM Prison and Probation Service), American probation (Federal Probation and Pretrial Officers Association, United States Court), Canadian probation (Ontario Ministry of Community Safety and Correctional Services), as well as in the works by Ukrainian and foreign scholars (A. Abaturov \& A. Korovin, A. Akkulev, Ch. Kamal, J. Petersilia, Ye. Shatankova, D. Whitfield et al.).

To study this experience, the following methods have been used: analysis, synthesis, comparison, systematization, generalization and self-evaluation.

\section{RESULTS}

Nowadays, there are differences in the nature, functions and organizational structure of probation service in different countries. Thus, in some countries the law defines probation as punishment (Sweden, Finland, Latvia), whereas in other countries it refers to some criminal measures (Great Britain), exemption from punishment (Estonia) or is not determined at all (the USA) (Shatankova, 2008, pp. 13-14).

In our opinion, such ambiguity has caused certain issues. In particular, it is still uncertain, whether execution of pre-trial actions should be conducted by the court, social security or prison administration. In addition, it is still necessary to decide which department probation service should be included in - the Ministry of Justice or the Ministry of Internal Affairs, as well as reconcile its structure.

Thus, probation service in Great Britain, Denmark, Japan, Finland, Norway, Latvia, the Czech Republic and Estonia is under the control of the Ministry of Justice; in the USA, Germany, Hungary, it is subordinate to the judiciary; in the Netherlands public prosecutor's office; in Sweden - prison authorities; in Singapore, probation service is under the guidance of the Ministry of Community Development and Sports (Akkulev, 2014; Confederation of European Probation, 2008; Kamal, 2005).

In accordance with these differences, there appears to be a need for considering experience of some countries in more detail.

Great Britain. The National Probation Service (NPS) for England and Wales is part of Her Majesty's Prison and Probation Service (HMPPS), which was transferred to the Ministry of Justice from the Home Office on May 9, 2007. It comprises 42 probation areas which are coterminous with police force area boundaries, served by 35 probation trusts.

An important part of the Probation Institute in England and Wales is professional training of probation officers. According to D. Whitfield (2001), in England and Wales probation officers' activities are specializied in the following areas: judicial work, writing special reports, work with family judges, work with sexual offenders, work in groups, work in prisons.

Thus, delivery of the current Probation Qualifications Framework ended with the final PQF cohort in 2016 and Her Majesty's Prison and Probation Service has replaced this with Community Justice Learning (CJL). The first phase of Community Justice Learning introduces a new qualification for Probation Officers and more flexible, inclusive access 
routes to this. The second phase is developing new qualifications for Probation Service Officers and Probation Case Administrators, along with a Community Justice Matrix which identifies bridges and ladders to career development across the sector. The qualification for Probation Officers is the Professional Qualification in Probation (PQiP). This continues to be work-based and comprises an integrated programme of applied academic learning and practice skills development, leading to a qualification at Honours Degree level 6. The skills components are assessed at work and lead to the award of a level 5 vocational qualification in Probation Practice.

Within Community Justice Learning all academic and vocational qualifications are assigned a level, which refers to both the previous Qualifications and Credit Framework (QCF) and the new Regulated Qualifications Framework (RQF). Level 4 qualifications are broadly similar to the first year of an undergraduate degree programme, such as Higher National Certificates, Certificates of Higher Education and level 4 Vocational Qualifications. Level 5 qualifications include Higher National Diplomas, Foundation Degrees, Diplomas of Higher Education, Level 5 Vocational Qualifications and Higher Apprenticeships. Level 6 qualifications include Honour Degrees, Graduate Certificates and Graduate Diplomas.

To be eligible to apply for the PQiP training programme, an applicant must be able to demonstrate that they have the following: 1) practice experience of either working with offenders or with other individuals exhibiting challenging behaviour and/or whose lives are in crisis, and 2) a degree or other recognised qualification at level 5 or above and 3) prior knowledge and understanding in four required knowledge modules: The Criminal Justice System, Crime and Criminal Behaviour, Penal Policy and Punishment, The Rehabilitation of Offenders. If their existing qualification covers three out of the four modules, they may be able to apply and complete the outstanding module while undertaking the PQiP training. These modules are available by distance learning and can be purchased direct from HMPPS contracted universities (Her Majesty's Prison and Probation Service, 2007).

The United States of America. In the United States, probation has existed over 150 years and has undergone significant changes. In some states, probation service has originated since 1878. According to J. Petersilia (1997), the US Probation and Pretrial Services System is not fully represented in society. The system of probation authorities is rather complicated, and agencies are scattered among many non-interlinked institutions, each with a wide range of rules and organizational structures.

All probation services, regardless of the level (state, county, city), have double subordination. General control over their activities is carried out by the Administrative Office at the Supreme Court of the United States through its probation departments. The total number of probation services in the country is around 6,000 units. It must be noted that organizational and managerial approaches to probation in the United States are not universal, and each state has its own specificity (United States Courts, 2017).

In 2016, online and full-time courses in probation were offered as compulsory. As a rule, they are designed for 160 hours of training in four weeks. Simultaneously, the US Probation and Pretrial Service System places the requirement that probation officers must strive for continuing professional development as well as motivates them toward enhancing knowledge of certain areas in professional activity. In addition, the Federal Judicial Center being the research and education agency of the judicial branch of the US government is aimed at developing training programmes and organizing seminars, workshops, full-time and online conferences, leadership and supervisory programmes. Each employee is trained in the workplace that covers various fields of professional activity, including studying the 
offender, reporting, alcohol or drug abuse, mental health treatment, firearms and security, personal budget planning, retirement planning etc. In order to become a probation officer, a candidate must meet the following requirements: age limit to 37 years old, a Bachelor's degree in Jurisprudence, perfect health, some experience in criminology and criminal justice, computer skills and FBI approval (United States Courts, 2017; Federal Probation and Pretrial Officers Association, 2017).

The US Probation and Pretrial Services System distinguishes the following categories of employees: a pre-trial officer, a probation officer, an assistant officer. The pre-trial officer is to work with a person who is charged with a criminal offense in order to prevent a repeated commission of crime and ensure their prompt appearance before a judge. A probation officer works with an offender after they have been found guilty or left prison. They are to ensure that the offender abides the law and does not commit a new crime. An assistant officer is to assist pretrial and probation officers, study the offender, collect information, prepare pretrial reports, work with correspondence and monitor low-risk offenders (United States Courts).

Canada. An important feature of Canadian probation is parole. Parole is a permission for a pisoner to be released before their period in prison is finished, with the agreement that they will behave well. During parole, the convict is entitled to live in society under certain conditions. If the convict violates these conditions, probation officers may send them back to prison. Parole officers not only monitor the convicts' activities, but also assist them in adapting to society. In order to become a probation officer, special qualifications and skills are not required. A bachelor's degree in Business Administration, Criminal Justice or National Security is enough for such a career. These programmes cover such important areas as management techniques, criminal justice procedures and security training. Parole and probation officers are trained in a number of professional schools. During the training, they develop self-defense skills, standard security and reporting procedures (Abaturov \& Korovin, 2012; Ontario Ministry of Community Safety and Correctional Services, 2016).

\section{CONCLUSIONS}

Summarizing the above-mentioned materials, we have drawn some conclusions. Firstly, the Probation Institute has become widespread both in continental and non-continental legal systems. It consists in "testing" the convict, so that they may avoid punishment, first of all, imprisonment. Secondly, work with offenders should be performed by highly qualified specialists who have a degree and who have passed specialized training courses in educational institutions subordinate to probation authorities. It is important that they should strive for professional development. In addition, probation officers must hold a Bachelor's degree (at least in Social Work), undergo professional training in penitentiary institutions. It is important that the content of probation officers' professional training should be constantly updated, taking into account new approaches and methods of working with convicts, which are recognized as effective.

Still, it is crucial to find out how to implement European practice in the national legislation as well as develop an effective mechanism for changing the modern approach to training probation officers. Thus, we believe it necessary to consider the abovementioned aspects in further researches.

\section{REFERENCES}

1. Abaturov, A. I. \& Korovin, A. A. (2012). Sluzhba probatsii: zarubezhnyi opyt. Kirov: Spektr-Print. 
2. Akkulev, A. Sh. (2014). Otdelnye voprosy probatsii. Vziato s https://www.zakon.kz 4598354-otdelnye-voprosy-probacii-akkulev-a.sh..html.

3. Confederation of European Probation. (2008). Probation in Europe updates. Retrieved from http://www.cep-probation.org/knowledgebase/probation-in-europe-update/.

4. Federal Probation and Pretrial Officers Association. (2017). FPPOA National Training Institute (NTI) 2017. Retrieved from http://www.fppoa.org.

5. HM Prison and Probation Service. (2017). FAQs. Retrieved from http://www.traintobeaprobationofficer.com/faqs/.

6. Kamal, Ch. (2005). Probation service in Singapore. Resource Material Series, 67, $61-74$.

7. Ontario Ministry of Community Safety and Correctional Services. (2016). Becoming a correctional services officer. Retrieved from https://www.mcscs.jus.gov. on.ca/english/corr_serv/careers_in_corr/become_corr_off/COTraining/cs_cotraining.html.

8. Petersilia, J. (1997). Probation in the United States. Crime and Justice, 22, 149-200.

9. Shatankova, E. N. (2008). Uslovnoe osuzhdenie i probatsiia za rubezhom (sravnitelnopravovoi analiz). (Avtoref. dis. kand. yurid. nauk). Gosudarstvennoe obrazovatelnoe uchrezhdenie vysshego professionalnogo obrazovaniia "Rossiiskaya pravovaya akademiya Ministerstva yustitsii Rossiyskoi Federatsii”, Moskva.

10. United States Court. (2017). Probation and pretrial officers and officer assistants. Retrieved from http://www.uscourts.gov/services-forms/probation-and-pretrialservices/probation-and-pretrial-officers-and-officer.

11. Whitfield, D. (2001). Introduction to the probation service (introductory series). Winchester: Waterside Press. 